\title{
Host reaction in paratenic fish hosts against 3rd stage larvae of Anguillicola crassus
}

\author{
Cs. Székely ${ }^{1, *}, J$ Pazooki ${ }^{2}$, K. Molnár ${ }^{1}$ \\ 'Veterinary Medical Research Institute, Hungarian Academy of Sciences, H-1143 Budapest, Hungária krt. 21, Hungary \\ ${ }^{2}$ Iranian Fisheries Research and Training Organisation, Department of Fish Diseases, POB 14155-6116 Tehran, Iran
}

\begin{abstract}
Many fish species of Lake Balaton (Hungary) serve as paratenic hosts for the 3rd stage larvae of the eel parasite Anguillicola crassus. The incidence of different phases of the host reaction varies with paratenic fish host but its nature is basically the same. The appearance of mononuclear cells around the larvae migrating in the tissues or in the abdominal cavity is regarded as a sign of cellular host reaction. The cells adhering to the surface of the larvae gradually assume an epithelioid shape and form a granuloma. With the advancement of the process the larvae and the epithelioid cells surrounding them undergo necrosis, and the granuloma becomes surrounded by a connective tissue capsule. In more chronic cases, the inside of the parasitic nodule surrounded by several layers of connective tissue is filled out by amorphous tissue and parasite debris. In the 'suitable paratenic hosts' Anguillicola sp. larvae not affected by the host's cellular reaction outnumber those affected by it, whereas in the 'less suitable paratenic hosts' the cellular reaction very rapidly forces the larvae into focl and destroys them.
\end{abstract}

KEY WORDS: Eel parasite A Anguillicola Paratenic hosts - Host reaction - Lake Balaton

\section{INTRODUCTION}

Anguillicola crassus, a nematode parasitizing in its adult stage the swimbladder lumen of eel Anguilla anguilla, is a well-known parasite of Japanese and European eels (Moravec \& Taraschewski 1988). It was brought into Europe in the early 1980s and subsequently spread throughout the European continent very rapidly. The parasite was first detected in Germany by Neumann (1985). Its spread and occurrence in Europe were described in detail by Køie (1991) and Moravec (1992) and much information is available on its development. In addition to the few early, mainly Asian, studies (Hirose et al. 1976, Egusa 1979), European authors (Haenen et al. 1989, Petter et al. 1989, De Charleroy et al. 1990, Kennedy \& Fitch 1990) have dealt with this subject. Like A. globiceps, the related species known from the Far East, $A$. crassus has been found to develop in a copepod intermediate host, in which infective 3rd stage larvae develop after ingestion of the 2nd stage larvae. Eels become infected after consuming the infected copepods: as a result of development in the swimbladder wall, 4 th stage larvae or preadult speci-

•E-mail: h8682sze@ella.hu mens develop which then reach maturity in the lumen of the swimbladder. Although this developmental cycle is undoubtedly valid, only the studies of Cannaerts (1989), Haenen \& van Banning (1990), Thomas \& Ollevier (1992), Höglund \& Thomas (1992), Székely (1994), and Pazooki \& Székely (1994) have paid attention to the fact that under natural conditions the eel, a species which only rarely feeds on plankton, may become infected by $A$. crassus through paratenic hosts. On the other hand, Kennedy et al. (1992) have argued that eels in nature may feed more on, and be more closely associated with, plankton than is usually assumed. The results obtained until now indicate that only eel species may act as a definitive host for $A$. crassus, while practically all fish species are potential paratenic hosts. Haenen \& van Banning (1990) recorded 5, Thomas \& Ollevier (1992) 16, and Székely (1994) 20 fish species as paratenic hosts. As a result, eels feeding on such paratenic hosts become infected (Székely unpubl.). The possibility of infection by that route has been confirmed experimentally by Haenen \& van Banning (1991) and Moravec \& Konecny (1994). Thomas \& Ollevier (1992) also mentioned that major differences exist in the incidence and prevalence of $A$. crassus larvae in the individual paratenic fish hosts. For instance, they found $A$. 
crassus larvae much more frequently in perches and gobies than in cyprinids, and reported that in the perch 4 th stage larvae and preadult specimens occurred along with the 3rd stage larvae.

Data on the viability of Anguillicola crassus larvae in paratenic hosts have been supplied by Thomas \& Ollevier (1992), Székely (1994, in press) and Pazooki \& Székely (1994), who demonstrated that in certain fish species (e.g the river goby Neogobius fluviatilis) more living larvae occurred than in others (e.g. in cyprinids). In cyprinids the majority of the larvae can be found in the abdominal cavity or gut wall of the fish, but most often in the serosa covering the gut, in encapsulated or necrotic form.

Data on the host reaction against larvae migrating in the swimbladder wall of eels have been publisheu, and the nature of the host reaction has been described by Haenen et al. (1989), Molnár et al. (1993, 1994) and Molnár (1994). Experimenting with antigens isolated from adult Anguillicola crassus, Buchmann et al. (1991) have established that such antigens can elicit an immune response, while Polzer \& Taraschewski (1993) have classified antigens from 3rd stage larvae of $A$. crassus. Similar studies have not yet been performed for the paratenic hosts of $A$. crassus.

The objective of this paper is to describe the different forms of host reaction against Anguillicola crassus larvae infecting paratenic hosts, and to point out the differences existing in the type of host reaction of different paratenic fish host species.

\section{MATERIAL AND METHODS}

Fish species infected by the larvae of Anguillicola crassus were collected between 1991 and 1993 (Table 1) during sample collections aimed at surveying the dynamics of infection in Lake Balaton, Hungary (Székely in press) and, on one occasion, from Lake Velence, Hungary (Pazooki \& Székely 1994).

The small fish were collected by electrofishing or with a narrow-meshed trawl net. After catching, the fish were transported to the laboratory in aerated cans or in foil bags inflated with oxygen, and then kept in aquaria. The fish were dissected within a few days of collection, and the prevalence, intensity and character of the host reaction, if any, were recorded. In cases that seemed to be of interest with a view to the host reaction, the larva-infected organs (primarily the gut) were fixed in $4 \%$ buffered formalin or in Bouin's solution. After embedding the blocks in paraffin wax, $4 \mu \mathrm{m}$ thick sections were prepared from them and stained with haematoxylin and eosin. Photographs were taken of the sections using a Jenaval microscope with a photographic attachment

\section{RESULTS}

As regards the type of the host reaction, both similarities and differences were present between the paratenic hosts studied.

In the river goby Neogobius fluviatilis practically no signs of host reaction were demonstrable, while in cyprinids the larvae were in most cases surrounded by macrophages, proliferating tissue or a connective tissue capsule, and numerous dead larvae could be seen within the capsule thus formed. In addition to the river goby, live larvae were found primarily in the pumpkinseed Lepomis gibbosus and ruffe Gymnocephalus cernua, while in the bleak Alburnus alburnus and other cyprinids only a limited number of free live idrvate and various forms of the host reaction were more prevalent.

Irrespective of the differences among fish species, the host reaction could be graded into several categories. (1) In all fish species some of the larvae (and in the river goby all of them) moved freely in the abdominal cavity and could be found in the gonads, intestinal wall, and swimbladder. No host cells adhered to their surface. (2) In other cases the larvae were located in the tissues, their presence was associated with slight regressive changes of the tissues, which manifested themselves in the separation of cell rows and accumulation of serum around the larva (Fig. 1). In some cases,

Table 1 Fish species examined and number of specimens processed in the period 1991 through 1993 from Lake Balaton and Lake Velence, Hungary

\begin{tabular}{|llr|}
\hline & Fish species & $\begin{array}{r}\text { No. of specimens } \\
\text { examined }\end{array}$ \\
\hline Bleak & Alburnus alburnus & 423 \\
Pumpkinseed & Lepomis gibbosus & 201 \\
River goby & Neogobius fluviatilis & 169 \\
Roach & Rutilus rutilus & 169 \\
White bream & Blicca bjoerkna & 78 \\
Rudd & Scardinius erythrophthalmus & 68 \\
Bitterling & Rhodeus sericeus amarus & 65 \\
Chinese rasbora & Pseudorasbora parva & 66 \\
Pike perch & Stizostedion lucioperca & 71 \\
Bream & Abramis brama & 39 \\
Ruffe & Gymnocephalus cernua & 102 \\
Gibel carp & Carassius auratus gibelio & 22 \\
Gudgeon & Gobio albipinnatus & 17 \\
European catfish & Silurus glanis & 14 \\
Pike & Esoxlucius & 8 \\
Asp & Aspius aspius & 7 \\
Perch & Perca fluviatilis & 5 \\
Common carp & Cyprinus carpio & 4 \\
Tench & Tinca tinca & 3 \\
Crucian carp & Carassius carassius & 1 \\
Rain bleak & Leucaspius delineatus & 1 \\
Brown bullhead & Ictalurus nebulosus & 1 \\
Total & 22 species & 1534 \\
\hline
\end{tabular}


larvae were detectable in the lumen of the major blood vessels of serous membranes as well (Fig. 2). (3) The appearance of macrophages loosely adhering to the surface of the larvae was often seen in fresh preparations, but it could not be demonstrated histologically. (4) In more severe cases the migrating larvae became surrounded by granulation tissue consisting of a few cell rows (Fig. 3), which contained histiocytes and round cells alike. The larvae surrounded by granulation tissue were alive, but their motility was restricted. The cells of the tissue surrounding the larvae assumed a form typical of epithelioid cells (Fig. 4), and, proliferating, they formed a nodule around the larvae. In some fish species, such as the European catfish Silurus glanis, the appearance of several hundred or even 1000 nodules on the serous membrane around the gut and stomach was not an uncommon finding (Fig. 5). The nodules were bound together into a single mass by the loose connective tissue. Within the nodule, however, the larvae appeared to be still viable. (5) In other cases

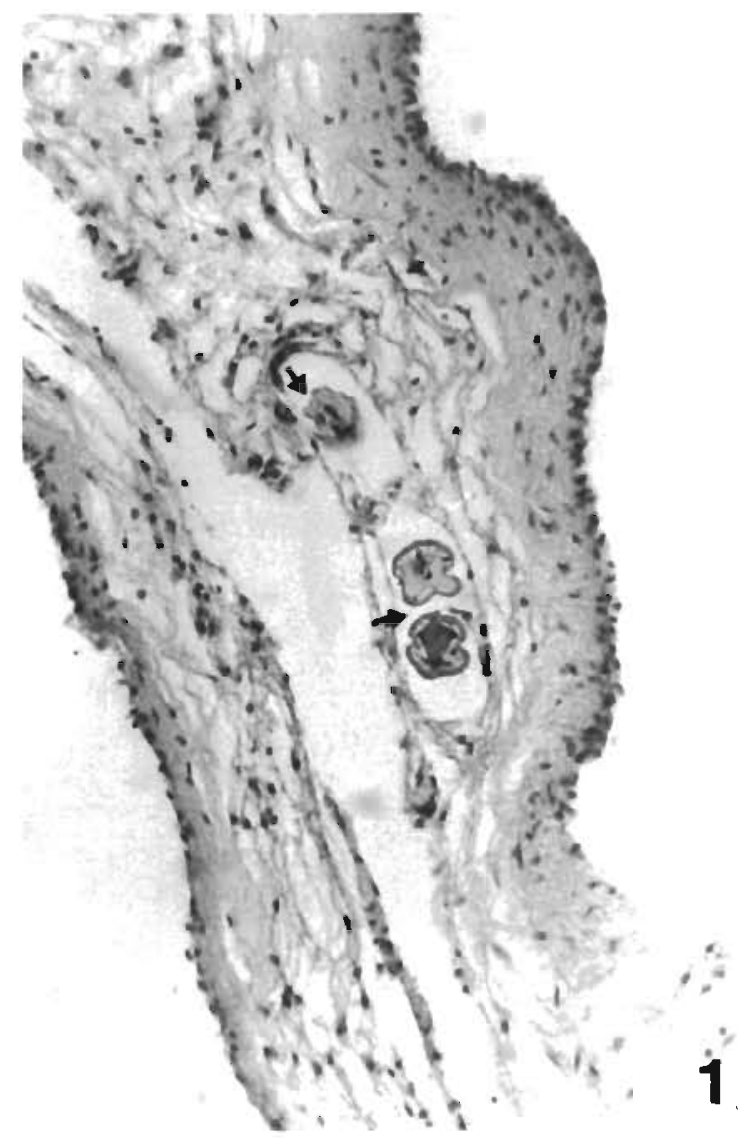

Fig. 1. Anguillicola crassus larval infection in ruffe Gymnocephalus cernua. Note the presence of 3rd stage larvae (arrows) in the serum-filled cavities formed in the loose connective tissue of the intestinal wall. Haematoxylin and eosin (H\&E), $\times 190$ the innermost cells of the epithelioid cell layer became necrotic (Fig. 6), while the outermost cells preserved their structure. The intact epithelioid layer and that undergoing necrosis became surrounded by a connective tissue capsule which initially consisted of a few cell rows and gradually became thicker. (6) In advanced cases the nodules were surrounded by a connective tissue capsule. These nodules contained both live and dead larvae. In other cases remnants of the dead larvae were still discernible in the middle of the nodule, but they were surrounded by necrotic amorphous tissue debris (Fig. 7). Such nodules rarely contained epithelioid cells which had mostly become replaced by split-up connective tissue.

Less often was the gross pathological picture consistent (Fig. 5); more frequently, however, various forms of the host reaction co-existed within a single fish specimen. In such cases, larvae freely moving in the abdominal cavity were accompanied by the simultaneous presence of nodules on the intestinal serosa, in the serous membrane, muscular layer and mucous membrane (Fig. 8). A pronounced seasonality could not be

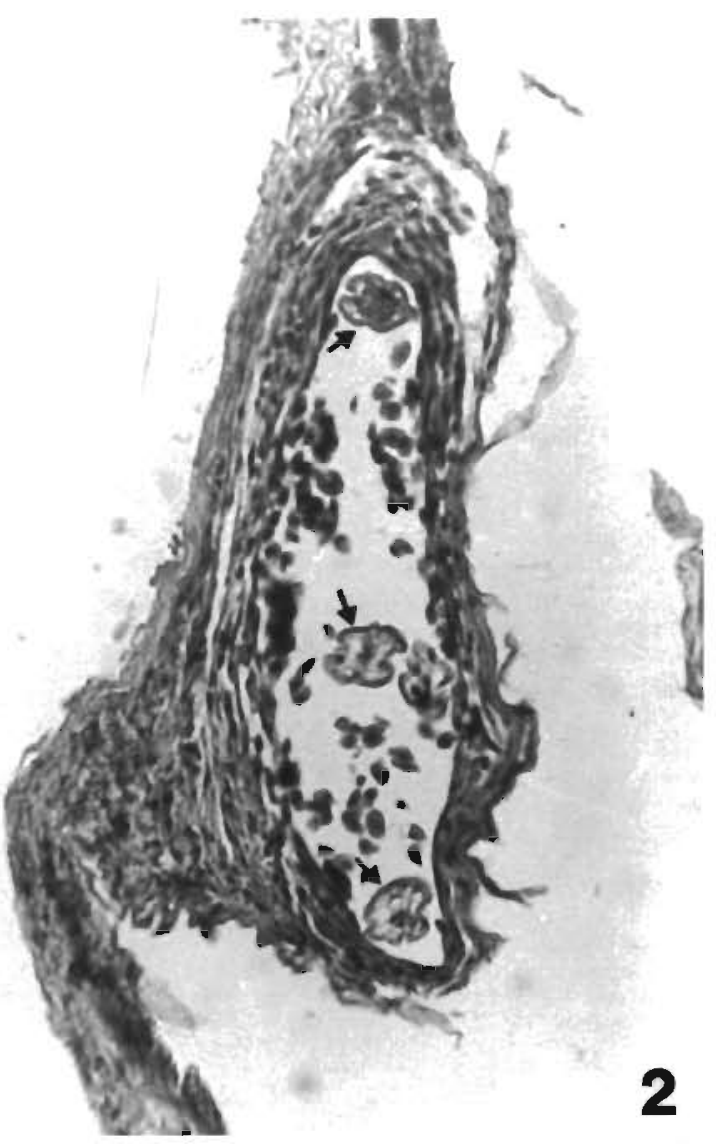

Fig. 2. Ruffe Gymnocephalus cernua. The infection by 3 rd stage larvae of Anguillicola crassus may also occur in the blood vessels of the serosa (arrows). $H \& E, \times 190$ 

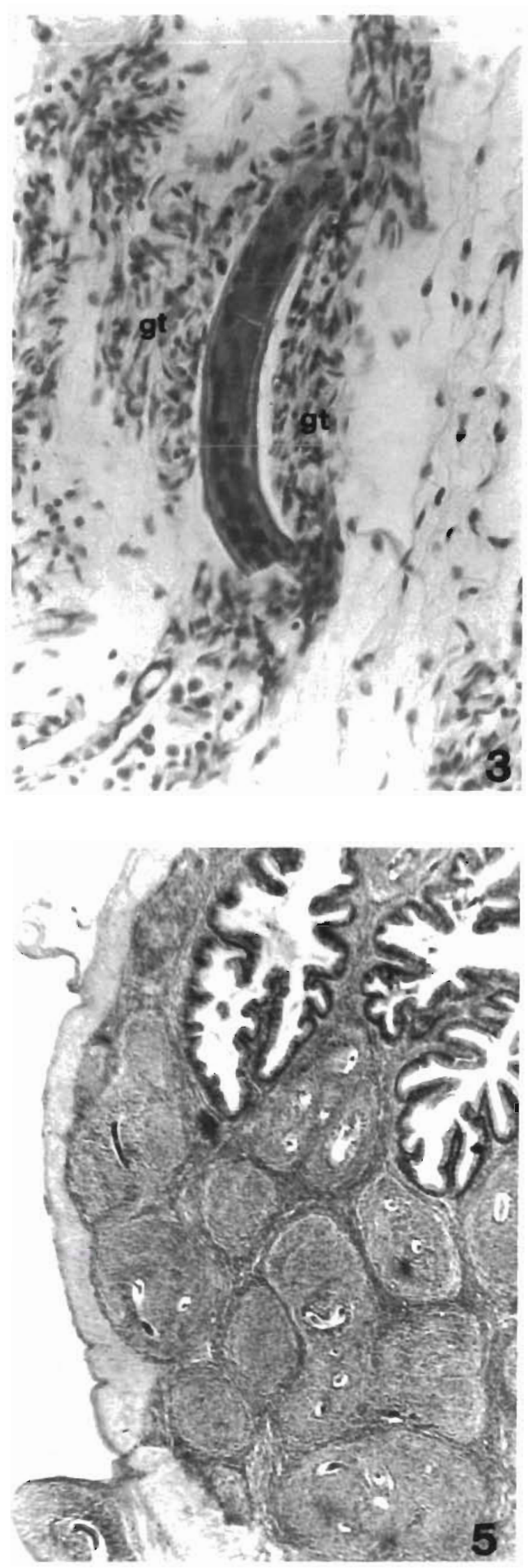

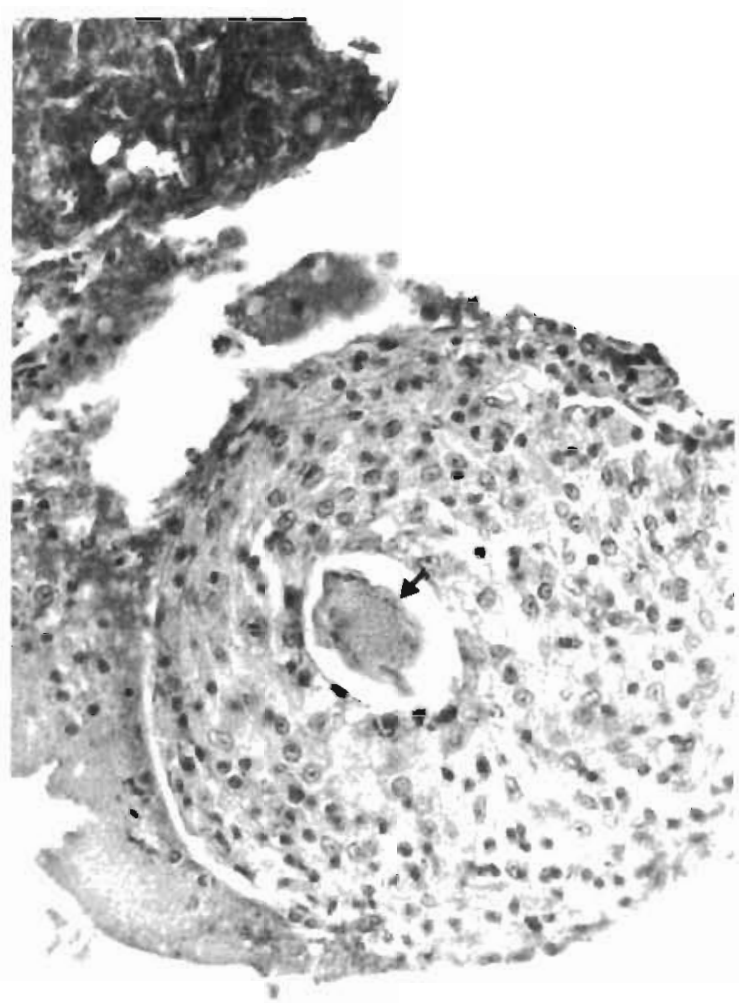

4

Fig. 3. Anguillicola crassus larva in the intestinal wall of the ruffe Gymnocephalus cernua. Host reaction is indicated by the appearance of granulation tissue (gt) consisting of some cell rows around the larva. H\&E, $\times 380$

Fig. 4. Bleak Alburnus alburnus. In more advanced phases of the host reaction the Anguillicola crassus larva (arrow) is surrounded by multiple layers of epithelioid cells. H\&E, $\times 380$

Fig. 5. Silurus glanis. Cross section of the intestinal wall from European catfish. The numerous nodules are bound into a single mass by loose connective tissue. $\mathrm{H} \& \mathrm{E}, \times 38$

demonstrated in the formation of nodules. In the period between spring and autumn, both new infections and chronic cases occurred. In winter and early spring, however, only chronic cases were recorded (Figs, 9 \& 10). In the latter cases, larvae could no longer be detected in the nodules which consisted of tissue debris and compact connective tissue surrounding it. At that time, the Anguillicola crassus origin of the parasitic nodule could only be inferred from the type of the process and from correlations established through regular fish dissections. 


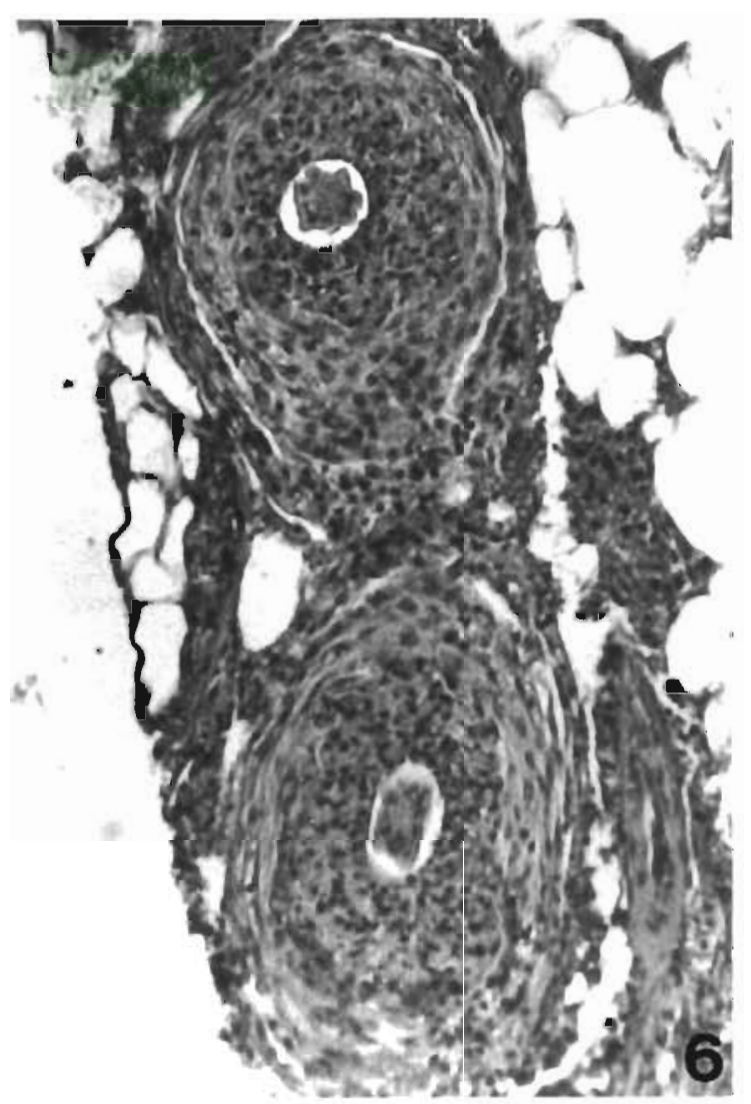

Fig. 6. Parasitic nodule containing Anguillicola crassus larvae on the serous membrane of the intestinal wall of roach Rutilus rutilus. The innermost cells of the epithelioid cell layer have undergone necrosis. The nodule is surrounded by a connective tissue capsule. $H \& E, \times 200$

Fig. 7. Ruffe Gymnocephalus cernua. In more advanced cases, the remnants of a dead Anguillicola crassus larva (arrow) are still discernible in the middle of the nodule but they are already surrounded by an amorphous tissue debris. H\&E, $\times 200$

Fig. 8. European catfish Silurus glanis. Anguillicola crassus larvae surrounded by nodules on the serosa (a), muscular layer (b) and lamina propria (c) of the intestinal wall. $H \& E, \times 40$

\section{DISCUSSION}

From the data reported by Székely (1994) it is known that the 3rd stage larva of Anguillicola crassus can be detected in the majority of fish species living in Lake Balaton. The same report has paid attention to the fact that the intensity and type of infection vary with species. In agreement with the observations of Thomas \& Ollevier (1992), Höglund \& Thomas (1992) and Székely (1994), the present results indicate that the type of host reaction varies with the species of paratenic host.
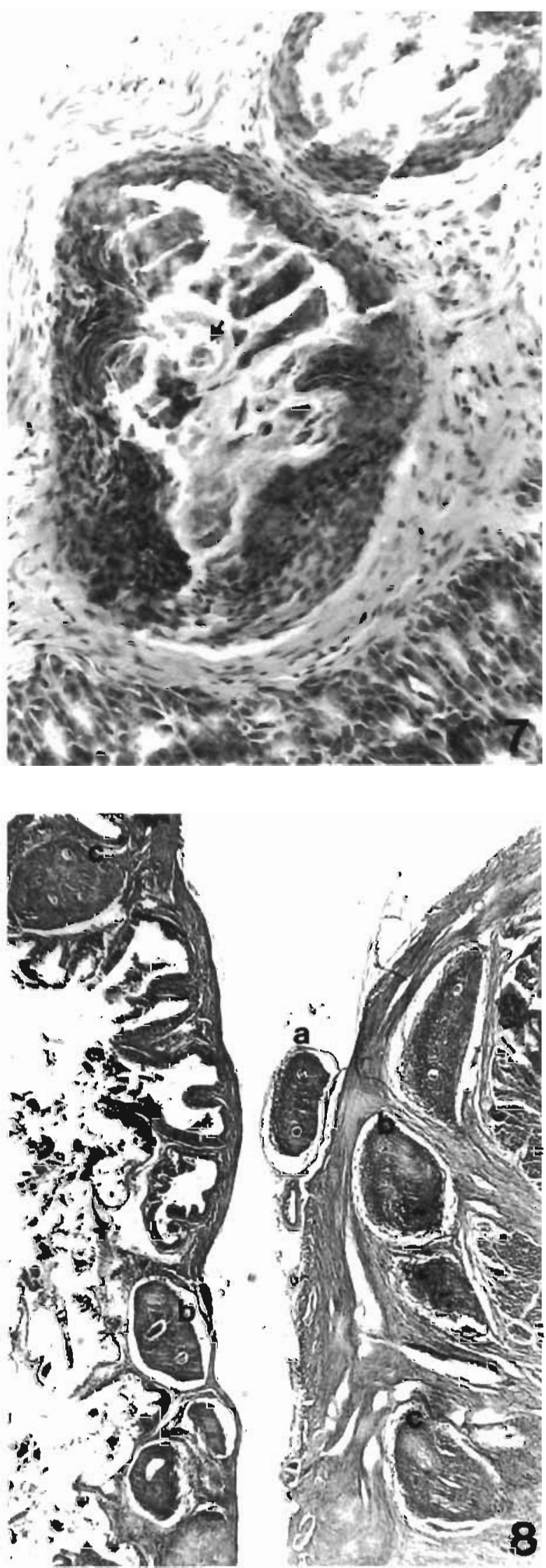


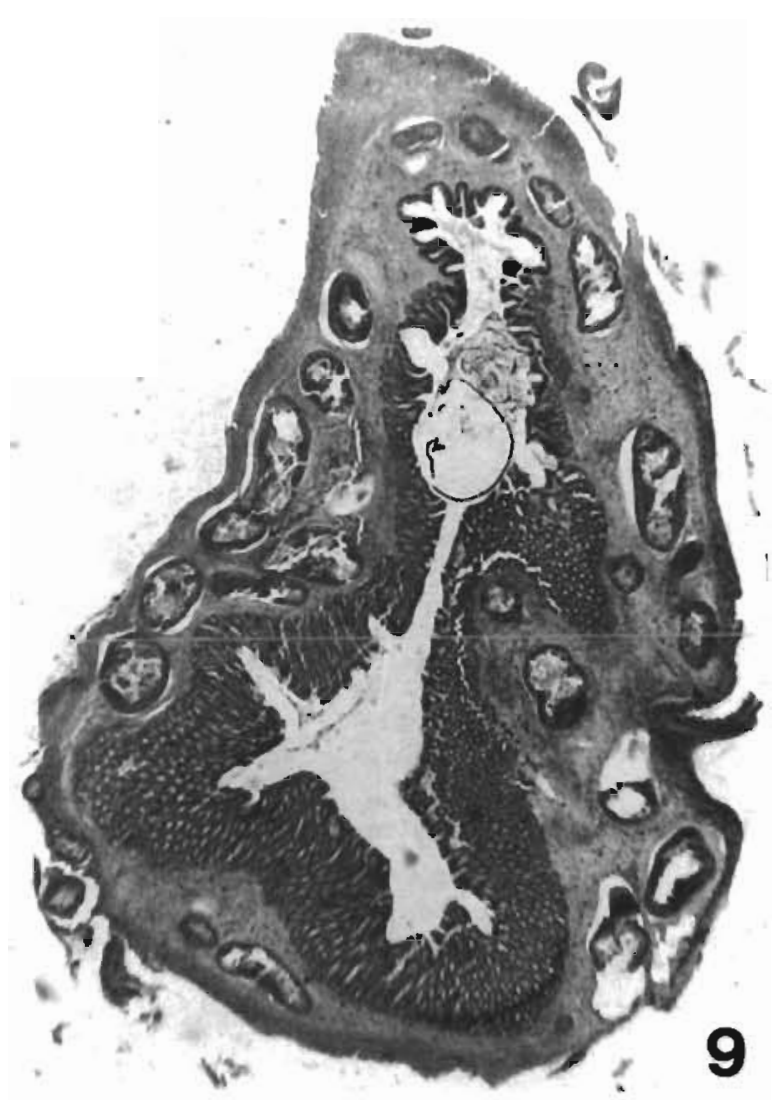

Fig. 9. Traces of an intensive Anguillicola crassus infection in the gut of ruffe Gymnocephalus cernua. Larvae are no longer detectable in the parasitic nodules. H\&E, $\times 40$

Although the findings presented in this paper are based on natural cases rather than experimental studies, the large number of fish species and specimens examined allowed us to draw conclusions on the mechanism and types of the host reaction. This also enabled us to deduce the sequence of phases of the host reaction, i.e. to classify the lesions into acute or chronic forms.

The river goby proved to be the most suitable paratenic host, as inferred by the presence of relatively numerous Anguillicola crassus larvae within a fish specimen without signs of a host reaction. According to the observations of Thomas \& Ollevier (1992), percid fishes also proved to be suitable paratenic hosts, as indicated by the presence of 4 th stage larvae and preadult specimens along with 3rd stage larvae in common perch. In perches surveyed in this study (e.g. Gymnocephalus cernua) no such advanced stages were found: besides the large numbers of live larvae, only encapsulated and dead larvae and different forms of host reaction could be recorded. All the fish species surveyed in this study behaved as typical paratenic hosts: within them, the larvae only preserved their viability but were unsuitable for further development.

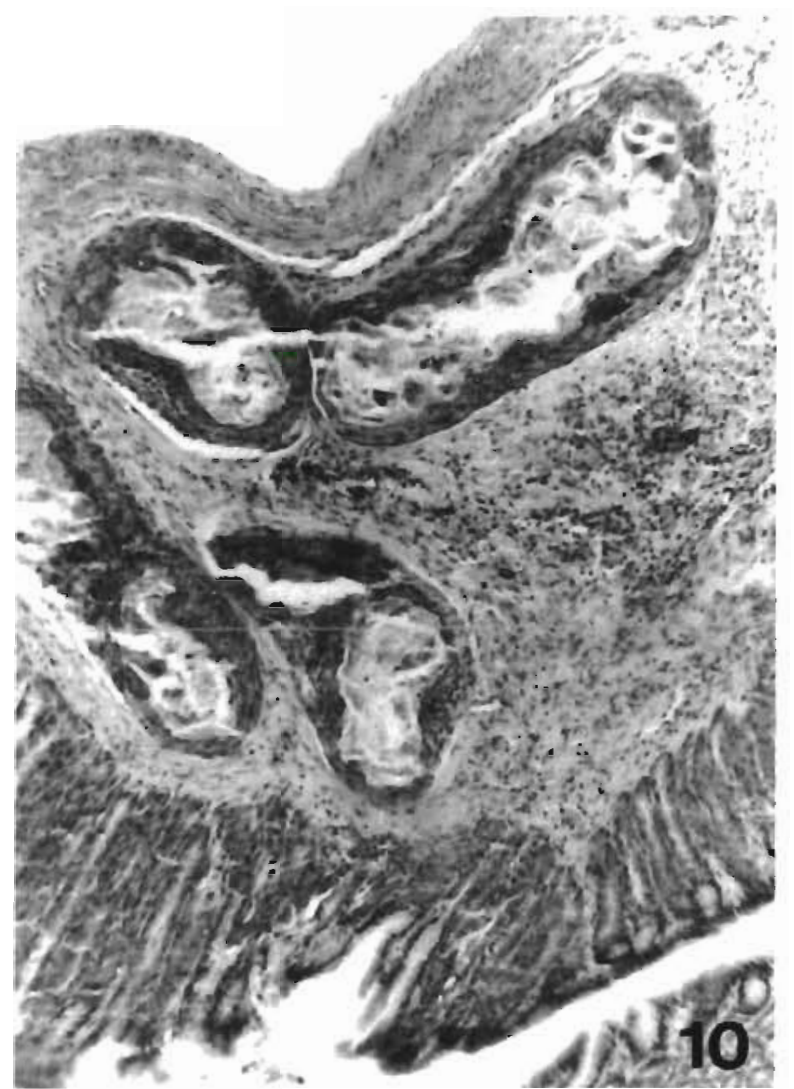

Fig. 10. Parasitic nodules in the intestinal wall of ruffe Gymnocephalus cernua. Chronic case. The presence of nodules containing tissue debris and surrounded by compact connective tissue indicates a passed-off Anguillicola crassus infection. $\mathrm{H} \& \mathrm{E}, \times 100$

Whether a given fish species is regarded as a suitable or a less suitable paratenic host depends on the major differences found among the fish species in the host reaction leading to the death of the parasite. Besides the goby, the highest number of live larvae were found in the percid fish $G$. cernua; however, in the latter fish species numerous encapsulated and dead larvae could also be identified, along with different forms of the host reaction. The finding that most of the fish species showed a severe infection in different seasons (see also Székely 1994) while the type of host reaction varied with species indicated that different fish species react to infection in a dissimilar manner. In the river goby the majority of larvae were alive and there was only minimal host reaction, which suggests that in this suitable paratenic fish host the larvae preserved their viability and infectivity for a long time. At the same time, the large number of encapsulated larvae found in cyprinids, surrounded by a diverse host reaction, suggests that these fish species are less suitable paratenic hosts. In these latter hosts the larvae induce a cellular host reaction even after an infection of shorter duration. In 
this respect, the ruffe, which was the best studied species in this work, occupies an intermediate position. Namely, in this species the live larvae present in large numbers were accompanied by larval forms attacked by a cellular reaction of diverse type, which finding also suggests a prolonged host response. In the formation of parasitic nodules, the host reaction of paratenic fish hosts against Anguillicola sp. larvae resembles that described for the parasite's definitive host, the eel (van Banning \& Haenen 1990, Csaba et al. 1993, Molnár 1994).

Histological studies fail to reveal the mechanism of infection of paratenic hosts. Live larvae occurred in the gut wall, swimbladder and abdominal cavity alike. The finding that larvae were also detected within the blood stream might suggest the possibility of larval migration via the blood stream, but it is more likely that the occurrence of larval stages in that location was a secondary phenomenon. The contact of mononuclear cells and larvae occurring freely in the abdominal cavity, on the serous membranes and in the tissues was consistently regarded as the mildest form of host reaction. In that case, these cells formed a thin capsule around the larvae. In the process of nodule formation, the reticuloendothelial cells adhering to the surface of the larvae assumed an epithelioid shape and surrounded the larvae in multiple cell rows.

Granuloma formation around 3rd stage larvae of Anguillicola crassus takes place in a manner similar to that observed by Molnár (1994) in eels, and basically corresponds to the process that Ferguson (1989) considers typical of the cellular host reaction of fish to parasites, and which has been regarded as typical for nematode infections of mammals (Poynter 1966 , Frenkel et al. 1988). The necrosis of larvae and epithelioid cells in the deep layers of the nodule consistently occurs after the formation of the connective tissue capsule; however, the histological picture fails to tell us whether the process is due to the insufficient nutrient supply of the encapsulated parts or whether special cytokines or other substances also have a role in its development. In advanced stages of nodule formation, when only amorphous tissue debris can be found in the place where epithelioid cells and helminths used to be, the role of $A$. crassus as an aetiological agent cannot be established. The nodule formed shows no difference from the parasitic nodules that ReichenbachKlinke (1954a, b) considers typical of nodule formation.

Usually, lesions representing the same stage of development were found within a given fish specimen. Despite this fact, an obvious seasonality could not be demonstrated in the formation and development of nodules (see also Székely 1994, in press). That process obviously depends on how much the host reaction has advanced after infection with a given larva. Marked differences seem to exist between fish species in the evolution of the host reaction: our observations (and unpublished experimental results of Székely) suggest that in cyprinids the host reaction manifests itself very soon after infection, in perches the larvae remain viable for a long period, while in the goby no appreciable host reaction takes place. A unique form of infection could be observed in European catfish fingerlings: a highly intensive infection and a cellular reaction which manifests itself in a marked nodule formation against each larva were demonstrable. That fish species is already a predator at a young age, and obviously takes up Anguillicola crassus larvae when feeding on small fry of other fish species. Still, it is surprising that, despite the supposedly gradual infection, the host reaction was found to be synchronous in the cases we studied.

Acknowledgements. The authors thank the staff of the Balaton Limnological Research Institution of the Hungarian Academy of Sciences for making available their research boat and crew for the fishing trips. This work was supported by the National Research Fund (OTKA), project no. T 6035, and by the financial help of the Fisheries Fund of the Hungarian Agricultural Ministry.

\section{LITERATURE CITED}

Buchmann K, Pedersen LO, Glamann J (1991) Humoral immune response of the European eel Anguilla anguilla to a major antigen in Anguillicola crassus (Nematoda). Dis Aquat Org 12:55-57

Cannaerts V (1989) Interactie van Anguillicola crassus, met enkele typische reservoirgastheren en de eindgastheer, Anguilla anguilla. M.Sc. dissertation, Catholic University of Leuven

Csaba Gy, Láng M. Sályi G, Ramotsa J, Glávits R, Rátz F (1993) The nematode Anguillicola crassus (Nematoda, Anguillicolidae) and its role in the death of eels in Lake Balaton during 1991 (in Hungarian, with English abstract) Magyar Állatorvosok Lapja 48:11-21

De Charleroy D, Grisez L, Thomas K, Belpaire C, Ollevier F (1990) The life cycle of Anguillicola crassus. Dis Aquat Org 8:77-84

Egusa S (1979) Notes on the culture of the European eel (Anguilla anguilla) in Japanese eel-farming ponds. Rapp PV Réun Cons Int Explor Mer 174:51-58

Ferguson HW (1989) Systemic pathology of fish. Iowa State University Press, Ames

Frenkel JK, Taraschewski H, Voigt WP (1988) Important pathologic effects on parasitic infections of man. In: Mehlhorn H (ed) Parasitology in focus. Springer-Verlag, Berlin, p 538-590

Haenen OLM, Grisez L, De Charleroy D, Belpaire C, Ollevier $F$ (1989) Experimentally induced infections of European eel Anguilla anguilla with Anguillicola crassus (Nematoda, Dracunculoidea) and subsequent migration of larvae. Dis Aquat Org 7:97-101

Haenen OLM, van Banning P (1990) Detection of larvae of Anguillicola crassus (an eel swimbladder nematode) in freshwater fish species. Aquaculture 87:103-109 
Haenen OLM, van Banning P (1991) Experimental transmission of Anguillicola crassus (Nematoda, Dracunculoidea) larvae from infected prey fish to the eel, Anguilla anguilla. Aquaculture 92:115-119

Hirose H, Sekino T, Egusa S (1976) Notes on the egg deposition, larval migration and intermediate host of the nematode Anguillicola crassus parasitic in the swimbladders of eels (in Japanese, with English abstract). Fish Pathol $11: 27-31$

Höglund J, Thomas K (1992) The black goby Ciobius niger as a potential paratenic host for the parasitic nematode Anguillicola crassus in a thermal effluent of the Baltic. Dis Aquat Org 13:175-180

Kennedy CR, Fitch DJ (1990) Colonization, larval survival and epidemiology of the nematode Anguillicola crassus, parasitic in the eel, Anguilla anguilla, in Britain. J Fish Biol 36:117-131

Kennedy CR, Nie P, Kaspers J, Paulisse J (1992) Are eels (Anguilla anguilla L.) planktnnir feeders? Evidence from parasite communities. J Fish Biol 41:567-580

Køie M (1991) Swimbladder nematodes (Anguillicola spp.) and gill monogeneans (Pseudodactylogyrus spp.) parasitic on the European eel (Anguilla anguilla). J Cons Int Explor Mer 47:391-398

Molnár K (1994) Formation of parasitic nodules in the swimbladder and intestinal walls of the eel Anguilla anguilla due to infections with larval stages of Anguillicola crassus. Dis Aquat Org 20:163-170

Molnár K, Baska F, Csaba Gy, Glávits R, Székely Cs (1993) Pathological and histopathological studies of the swimbladder of eels Anguilla anguilla infected by Anguillicola crassus (Nematoda: Dracunculoidea). Dis Aquat Org 15: $41-50$

Molnár K, Székely Cs, Perényi M (1994) Dynamics of Anguillicola crassus (Nematoda: Dracunculoidea) infection of eels of Lake Balaton, Hungary. Folia Parasitol 41:193-202

Moravec F (1992) Spreading of the nematode Anguillicola crassus (Dracunculoidea) among eel populations in Europe. Folia Parasitol 40:247-248

Moravec F, Konecny R (1994) Some data on the intermediate and paratenic hosts of the nematode Anguillicola crassus Kuwahara, Niimi et ltagaki 1974 (Dracunculoidea), a swimbladder parasite of eels. Folia Parasitol 41:65-70

Responsible Subject Editor: W. Körting, Hannover, Germany
Moravec F, Taraschewski $H$ (1988) Revision of the genus Anguillicola Yamaguti, 1935 (Nematoda: Anguillicolidae) of the swimbladder of eels, including descriptions of two new species, A. novaezelandlae sp. n. and A. papernai sp. n. Folia Parasitol 35:125-146

Neumann W (1985) Schwimmblasenparasit Anguillicola bei Aalen. Fisch Teichwirt 36:322

Pazooki J, Székely Cs (1994) Survey of the paratenic hosts of Anguillicola crassus in Lake Velence, Hungary. Acta Vet Hung 42:87-97

Petter AJ, Fontaine YA, Le Belle N (1989) Etude du développement larvaire de Anguillicola crassus (Dracunculoidea) chez un Cyclopidae de la région parisienne. Ann Parasitol Hum Comp 64:347-355

Polzer M, Taraschewski $H$ (1993) Identification and characterization of proteolytic enzymes in the developmental stages of the eel-pathogenic nematode $A$. crassus. Parasitol Res 79:24-27

Pornter $D$ (1066) Some tissue reactions to the nendulude pardsites of animals. In: Dawes B (ed) Advances in parasitology 4. Academic Press, London, p 321-383

Reichenbach-Klinke HH (1954a) Untersuchungen über die bei Fischen durch Parasiten hervorgerufenen Zysten und deren Wirkung auf den Wirtskörper. Teil I. Zeitschr Fisch Hilf wissensch 3:NF 565-636

Reichenbach-Klinke HH (1954b) Untersuchungen über die bei Fischen durch Parasiten hervorgerufenen Zysten und deren Wirkung auf den Wirtskorper. Teil II. Zeitschr Fisch Hilfwissensch 4:NF 1-52

Székely Cs (1994) Paratenic hosts for the parasitic nematode Anguillicola crassus in Lake Balaton, Hungary. Dis Aquat Org 18:11-20

Székely Cs (in press) Dynamics of Anguillicola crassus (Nematoda: Dracunculoidea) larval infection in paratenic host fishes of Lake Balaton, Hungary. Acta Vet Hung

Thomas K, Ollevier F (1992) Paratenic hosts of the swimbladder nematode Anguillicola crassus. Dis Aquat Org 13: 165-174

van Banning P, Haenen OLM (1990) Effect of the swimbladder nematode Anguillicola crassus in wild and farmed eel, Anguilla anguilla. In: Perkins FO, Cheng TC (eds) Pathology in marine science. Academic Press, New York, p $317-330$

Manuscript first received: June 15, 1995

Revised version accepted: February 27, 1996 